ZBigniew ZioŁo

Uniwersytet Pedagogiczny, Kraków, Polska

\title{
Rola przemysłu i usług w kształtowaniu gospodarki opartej na wiedzy
}

\section{The Role of Industry and Services in the Development of a Knowledge-Based Economy}

\begin{abstract}
Streszczenie: Nasilający się proces kształtowania społeczeństwa informacyjnego stwarza nowe uwarunkowania dla funkcjonowania i rozwoju wszystkich sektorów życia gospodarczego, społecznego i kulturowego, w tym także dla przemysłu i usług. Na tym tle w pracy podjęto problematykę miejsca przemysłu i usług w gospodarce, mechanizmy wdrażania innowacji oraz przedstawiono wysokości nakładów finansowych na działalność badawczo-rozwojową dominujących światowych korporacji, w tym według sektorów oraz według krajów lokalizacji ich zarządów.
\end{abstract}

Abstract: An increasing formation process of the information society creates new conditions for the operation and development of all sectors of economy, social and cultural life, including industry and services. In this field the paper considers the issues of role of industry and services in economy, mechanisms of innovation implementation, and presents amount of financial expenses spent for R\&D of leading global corporations, by sector and country of their HQ.

Słowa kluczowe: badania i rozwój, gospodarka oparta na wiedzy, innowacje, korporacje światowe, przemysł, usługi

Key words: R\&D, knowledge-based economy, innovations, global corporation, industry, services

Nasilający się proces rozwoju cywilizacyjnego przejawiający się w przechodzeniu od industrialnej i postindustrialnej fazy rozwoju do fazy społeczeństwa informacyjnego oddziałuje na wszystkie segmenty życia społecznego, gospodarczego i kulturowego. Towarzyszy temu zmiana bazy ekonomicznej, która stwarza nowe uwarunkowania funkcjonowania i rozwoju gospodarki oraz wpływa na podnoszenie jakości i poziomu życia społeczeństwa. W nowej fazie społeczeństwa informacyjnego podstawą rozwoju jest nauka a gospodarka opiera się na wiedzy. Wiedza staje się towarem, który pozwala na zwiększanie efektywności gospodarowania i jest przedmiotem wymiany a w konsekwencji staje się strategicznym czynnikiem pobudzania wzrostu gospodarczego świata, grupy państw, poszczególnych krajów, a także 
układów regionalnych i lokalnych. Znaczącą rolę w kształtowaniu gospodarki opartej na wiedzy odgrywają nowoczesny przemysł i usługi. Obejmują one nie tylko nowe intensywnie rozwijające się branże przemysłu „wysokiej techniki”, ale także modernizowane tradycyjne branże. Wdrażana w ich procesach technologicznych automatyzacja i robotyzacja pozwalają na podejmowanie nowoczesnych i bardziej konkurencyjnych produktów. Informacyjna faza rozwoju wprowadza także nowe rodzaje usług związane np. z obsługą pojawiających się urządzeń, obsługą biznesową, logistyką, magazynowaniem $\mathrm{i}$ in.

Otwierają się w ten sposób dla geografii przemysłu i usług nowe problemy badawcze, których celem jest poznawanie nowych reguł ich kształtowania się w coraz bardziej różnicujących się układach przestrzennych oraz określania ich efektywności, co jest niezbędne dla wyznaczania dalszych kierunków przemian i przedstawiania propozycji działań na rzecz racjonalnego kształtowania tych procesów ${ }^{1}$. Wymaga to ciągłego poszukiwania coraz doskonalszych metod analizy celem w miarę precyzyjnego określania funkcji przemysłu i usług w kształtowaniu gospodarki opartej na wiedzy. W świetle przedstawionych założeń w niniejszych rozważaniach podjęta będzie problematyka miejsca przemysłu i usług w gospodarce, mechanizmy wdrażania innowacji a następnie ich częściowa weryfikacja w świetle nakładów na prace badawczo-rozwojowe dominujących światowych korporacji.

\section{Miejsce PRZEMYSŁu I USŁUG W GOSPODARCE}

W procesie rozwoju gospodarczego nadal podstawowe znaczenie ma działalność przemysłowa. Podkreślał to m.in. po ogłoszeniu wyników wyborów w swoim przemówieniu prezydent Francji F. Hollande mówiąc o konieczności reindustrializacji. „Przypomniał, że siłą Francji jest produkcja przemysłowa i jej wzmocnienie uczynił najważniejszym z priorytetów”. Podkreślił, że „siła gospodarki niemieckiej bierze się z olbrzymiej nadwyżki eksportowej generowanej przez przemysł”. Następnie „w Stanach Zjednoczonych i Wielkiej Brytanii realizowana jest polityka reindustrializacji, w tym wycofywania części inwestycji z Chin". Podobnie intensywny rozwój Chin wynika w głównym stopniu z tego, że stały się one fabryką świata, w znacznej mierze dzięki temu, że stworzyły olbrzymią sieć infrastrukturalną, mają duże zasoby taniej siły roboczej oraz stabilność i przewidywalność polityki

${ }^{1}$ W literaturze przedmiotu pojawiały się poglądy, że gospodarka naszego kraju znajduje się w fazie postindustrialnej, która charakteryzuje się wzrostem znaczenia działalności usługowej a spadkiem znaczenia przemysłu. Głoszono je na podstawie analizy danych statystycznych dotyczących zmian struktury zatrudnienia w gospodarce narodowej w której coraz większy udział stanowiły sektory usługowe. Tymczasem wzrost znaczenia usług nie jest wynikiem ich intensywnego rozwoju, ale zmniejszania poziomu zatrudnienia w przemyśle, który następował w wyniku upadku bądź likwidacji wielu przedsiębiorstw. Upadek ten wynikał z wielu czynników związanych m.in. z produkcją przestarzałych technologicznie produktów, które wobec wdrażania reguł gospodarki rynkowej i otwarcia się na rynki zachodnie nie były na nich konkurencyjne, wadliwie przeprowadzonej restrukturyzacji i wrogich przejęć, niewłaściwych metod zarządzania oraz silnej ingerencji czynnika politycznego, często posługującego się populistycznymi hasłami (Gorzelak 2009; Kieżun 2012; Mikołajewicz 2006; Rachwał 2004; Raport polskiego lobby przemysłowego 2012). 


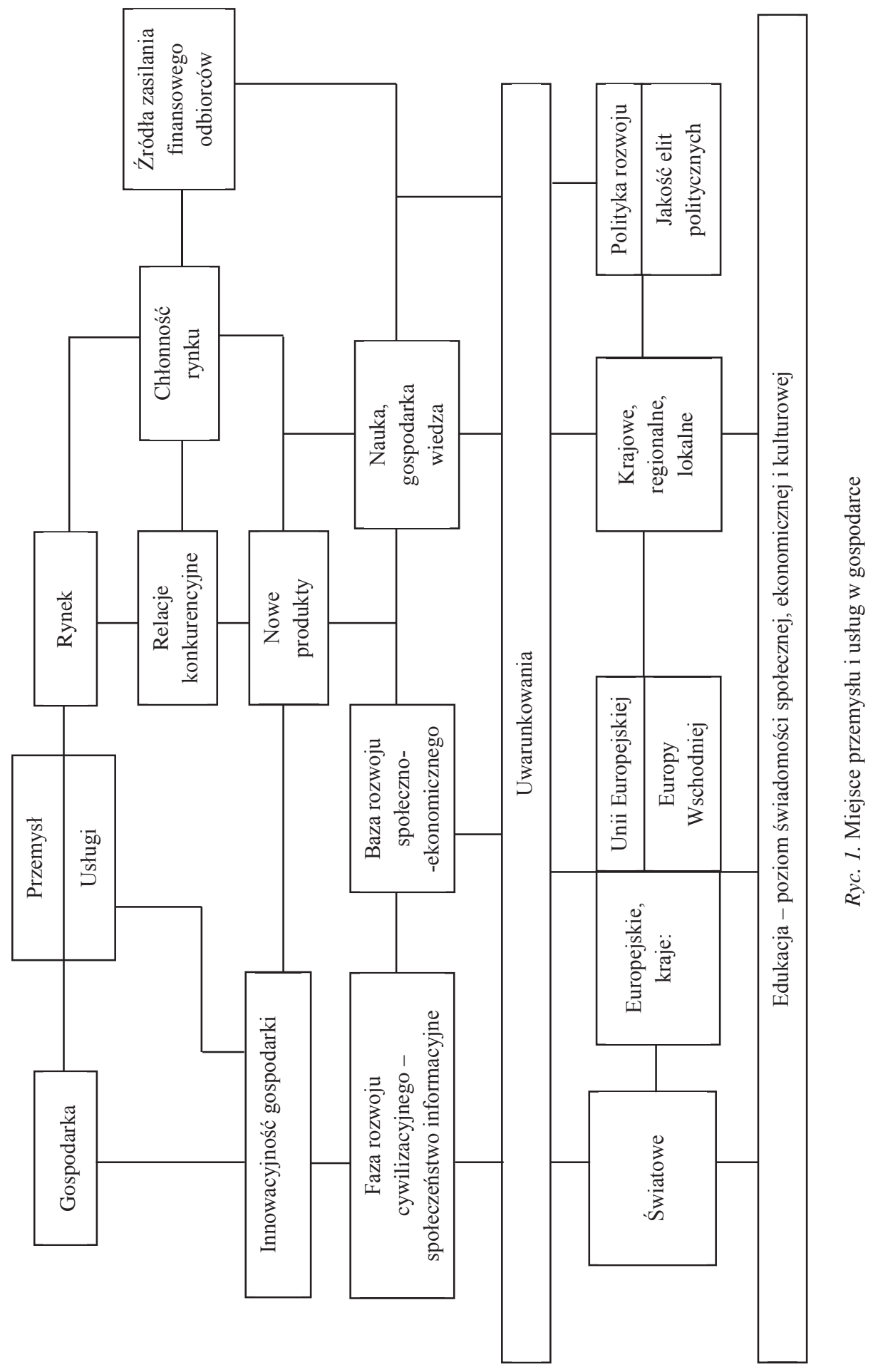


gospodarczej. Natomiast podstawową barierą rozwoju Indii jest brak sprawności państwa w zakresie zbudowania infrastruktury stabilności gospodarczej (Domarecki, Petru 2012).

W dobie gospodarki opartej na wiedzy konieczny jest rozwój działów odznaczających się dużym zaangażowaniem wiedzy i wysokiej technologii. Dlatego w procesie zarządzania gospodarką ważnym zagadnieniem jest przyśpieszenie procesów rozwoju przedsiębiorstw poprzez ułatwienie dostępu do nowych rozwiązań technologicznych i organizacyjnych (Kudełko 2011, 2013; Rachwał 2006, 2011). Główny ciężar na rzecz rozwoju innowacyjności pozostaje w rękach państwa, bowiem mechanizm rynkowy nie jest w tym względzie skutecznym regulatorem i instrumentem wzrostu innowacyjności. Związane jest to $\mathrm{z}$ dużą barierą, którą tworzą znaczące nakłady inwestycyjne oraz długim okresem zwrotu i wysokim ryzykiem (Mikołajewicz 2007). We współczesnym rozwoju rola przemysłu jako nośnika innowacji działalności produkcyjnej a także całej gospodarki jest więc szczególnie ważna (Sadowski 2006; Prusek 2009).

Na tym tle wydaje się koniecznością dążenie do określenia miejsca przemysłu i usług w gospodarce, które odnoszą się do uwarunkowań naszego kraju (ryc. 1). Określenie tego mechanizmu i zachodzących relacji w konwencji analizy systemowej wydaje się ważne dla poznania procesu oraz możliwości sterowania nimi w oparciu o reguły efektywności ekonomicznej przedsiębiorstwa, sektora przemysłu oraz całej gospodarki narodowej.

Przemysł i związane z nim usługi nie są bowiem odizolowanymi sektorami a ich poziom konkurencyjności w zasadniczym stopniu związany jest z kształtowaniem życia społecznego oraz stopniem innowacyjności gospodarki. Produkty przemysłu oraz oferowane usługi weryfikowane są na rynku w wyniku relacji konkurencyjnych zachodzących między producentami. Wpływają one na rozmiary i chłonność rynku, który związany jest bardzo ściśle z potencjałem ekonomicznym źródeł zasilania oraz z zasobami finansowymi potencjalnych odbiorców (gospodarstw domowych, innych przedsiębiorstw, instytucji, eksportu). Zwiększające się zasoby finansowe poprzez wzrost popytu na produkty w zasadniczym stopniu zwiększają możliwości produkcyjne przemysłu, natomiast zmniejszanie się popytu wpływa na ograniczanie produkcji i możliwości pełnego wykorzystania potencjału produkcyjnego, co w konsekwencji nie sprzyja także działalności inwestycyjnej przedsiębiorstw.

Innowacyjność gospodarki w zasadniczym stopniu warunkują nowe produkty, które umożliwiają podnoszenie efektywności gospodarowania. Podstawowe znaczenie w tym zakresie ma nauka, która pozwala na wzrost gospodarki opartej na wiedzy i w zasadniczym stopniu zmienia dotychczasową bazę ekonomicznego rozwoju oraz umożliwia przechodzenie do fazy społeczeństwa informacyjnego.

Duże znaczenie w tym zakresie odgrywają różnego typu uwarunkowania, które mogą wpływać na przyspieszanie lub opóźnianie procesu rozwoju. Podstawowe znaczenie mają uwarunkowania światowe i europejskie, wśród których należy wyróżnić uwarunkowania w strukturze Unii Europejskiej oraz krajach Europy Wschodniej, które do tej pory pozostają jeszcze poza strukturami unijnymi, ale należy wnosić, że w przyszłości do niej wejdą. Znaczącą rolę odgrywają także uwarunkowania krajowe, regionalne a także lokalne, które poprzez swoje działania mogą wpływać na podnoszenie lub osłabianie swojej pozycji konkurencyjnej. Wraz z podnoszeniem pozycji konkurencyjnej układów przestrzennych dla 
przyciągania zewnętrznych czynników rozwoju, ważnym zagadnieniem są także działania na rzecz aktywizacji wewnętrznych czynników przejawiających się w dążeniu do wygospodarowania własnych zasobów rozwojowych (Zioło 2010; Zioło, Rachwał 2006).

Przedstawione miejsce przemysłu i usług w gospodarce oraz warunkowania wynikające z otoczenia stanowią bardzo ważne przesłanki dla podejmowania określonej polityki rozwoju (Prusek 2009; Kudełko 2010, 2011). Polityka ta zależy w zasadniczym stopniu od jakości elit reprezentujących władzę ustawodawczą, instytucje rządowe i samorządowe. Elity te tworzą osoby wybrane w demokratycznych wyborach przez społeczeństwo. Stąd ich jakość w głównym stopniu zależy od jakości i poziomu kapitału społecznego (Kamińska, Heffner 2010).

Dlatego szczególnie ważnym problemem w procesie rozwoju gospodarczego, społecznego i kulturowego jest odpowiedni poziom świadomości społecznej, ekonomicznej, kulturowej i politycznej, który w zasadniczym stopniu zależy od działalności edukacyjnej, na poszczególnych etapach kształcenia (od przedszkola do studiów wyższych), ale także edukacji społeczeństwa zarówno poprzez zorganizowane formy kształcenia, dokształcania i doskonalenia zawodowego jak i przez racjonalną politykę i treści przekazywane przez media. W tym zakresie bardzo ważnym zagadnieniem jest określenie w jakim stopniu media, poprzez prezentowane treści, rozwijają myślenie i aspiracje społeczeństwa oraz pobudzają go do aktywnego działania i wpływają na podnoszenie poziomu kulturowego, czy też oferują populistyczne treści, które nie spełniają wspomnianych zadań. Zachodzi jednak pytanie, czy media w pogoni za zyskiem nie obniżają poziomu i nie dostosowują przekazywanych treści do zapotrzebowania stojących na niższym poziomie odbiorców, celem zwiększenia swojej oglądalności, czy poczytności. Dlatego znacząca rola w tym zakresie przypada elitom, które dają przyzwolenie na obniżanie jakości zasobów intelektualnych społeczeństwa. Pojawiające się dosyć często opinie wyrażane w różnej formie przez przedstawicieli elit o kiepskiej jakości społeczeństwa, świadczą o niezrozumieniu ich funkcji lub nieprzygotowaniu ich członków do spełniania swojej roli. Przecież to elity odpowiadają za jakość społeczeństwa i nikt ich z tego zadania nie może zwolnić ${ }^{2}$

Zarysowany model podkreśla znaczącą rolę przemysłu i usług w gospodarce jako czynników stymulujących wzrost gospodarczy funkcjonujących w określonej strukturze otoczenia. Dlatego problematyka ta wymaga coraz precyzyjniejszego poznania i doskonalenia a następnie wdrażania do praktyki gospodarczej, życia społecznego i kulturowego oraz działalności politycznej. Niewątpliwie przyczyniać się to będzie do zwiększenia znaczenia prac geograficznych oraz możliwości wykorzystania ich w praktyce gospodarczej.

\section{MECHANIZMY WDRAŻANIA INNOWACJI}

Wdrażanie innowacji do działalności podmiotów gospodarczych i instytucji jest procesem złożonym i obejmuje różne etapy, które wykazują między sobą wzajemnie zależności (ryc. 2).

2 Podejmując problematykę ochrony konsumenta, M. Szreder słusznie podkreśla odpowiedzialność państwa za poziom wiedzy społeczeństwa twierdząc, że ,państwo ma instrumenty i środki, aby wziąć na siebie odpowiedzialność za edukację społeczeństwa, której celem jest zmniejszenie ryzyka podejmowania przez niego złych decyzji” (M. Szreder, „Obywatel musi wiedzieć”, Rzeczpospolita, 28 sierpnia 2012). 


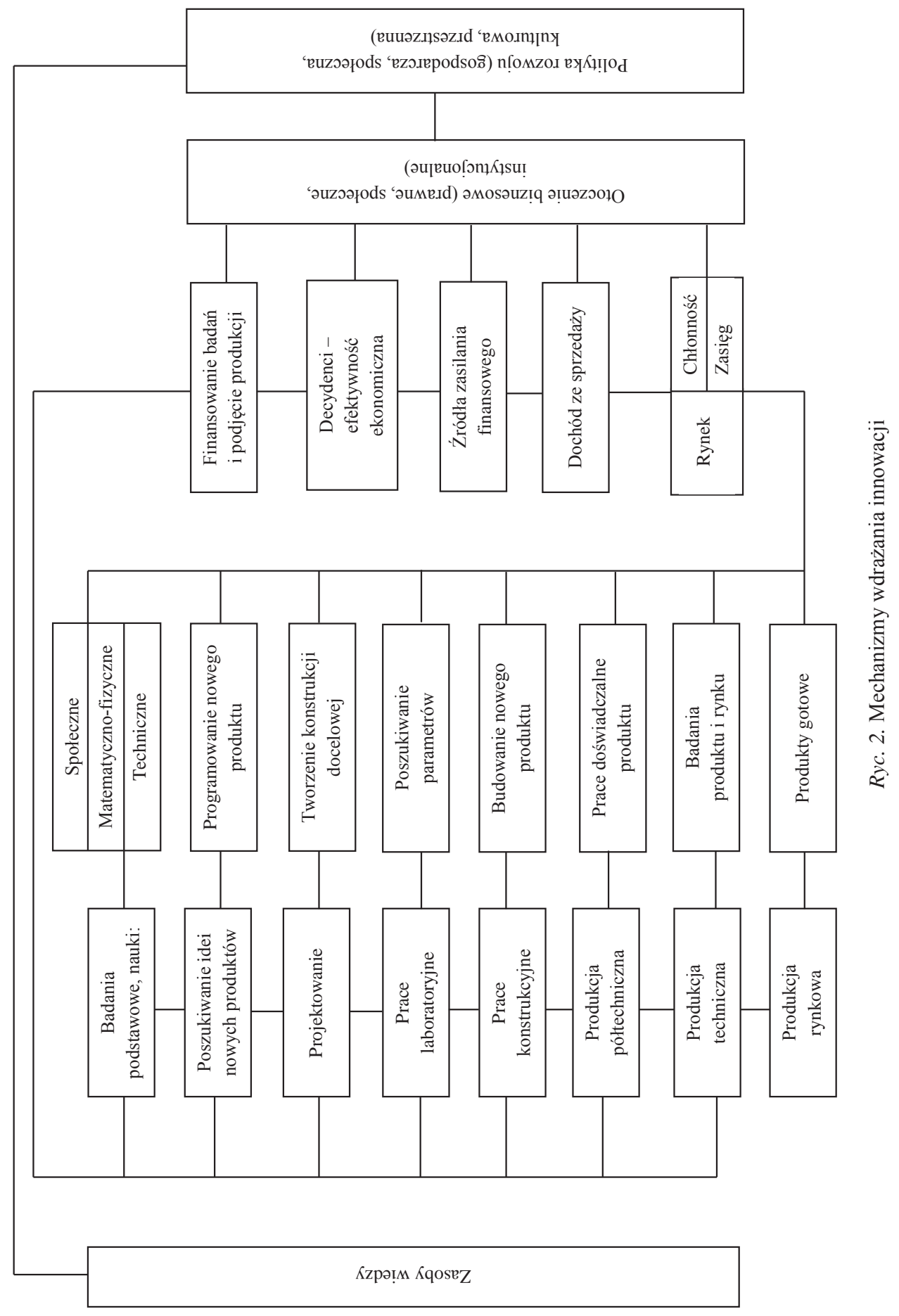


W procesie tym szczególnie ważną rolę odgrywają badania podstawowe szczegółowych dyscyplin naukowych, które w drodze coraz precyzyjniejszej analizy wyjaśniają proces kształtowania danego zjawiska z określonych punktów widzenia. Dążą one do poznania jego struktury, wyodrębnienia funkcjonalnych elementów oraz określenia relacji zachodzących między nimi. Drugą grupę tworzą dyscypliny syntetyzujące wyniki wyspecjalizowanych nauk szczegółowych w celu stworzenia określonych całości. Na ich polu wypracowywane są pewne idee, które przekształcają się w koncepcje będące podstawą do prowadzenia analiz teoretycznych i ujęć modelowych. Wypracowane idee i ujęcia modelowe weryfikowane są w badaniach laboratoryjnych, obserwacjach, które często odsłaniają nowe możliwości poznawcze i prowadzą do budowania nowych wzorców badawczych. Podstawową rolę w tym zakresie odgrywają badania prowadzone na gruncie nauk matematycznych, fizyczno-chemicznych, przyrodniczych, technicznych i społecznych.

Osiągnięte wyniki badań podstawowych oraz potrzeby życia prowadzą do poszukiwania idei nowych produktów, które mogą wpływać na osiąganie pewnych korzyści ekonomicznych, militarnych i handlowych. Prowadzi to do programowania nowego produktu oraz dokonania jego wstępnej oceny przydatności dla określonych celów (np. gospodarczych, militarnych, medycznych, żywieniowych, hodowlanych). Często również praktyka daje przesłanki do poszukiwania nowych idei oraz wyznacza nowe kierunki badań podstawowych (np. pojawiła się potrzeba bardziej konkurencyjnych i bardziej nowoczesnych produktów).

$\mathrm{Na}$ ich podstawie uruchamia się prace projektowe, które służą do tworzenia docelowej konstrukcji, czy nowych metod zarządzania.

Prototypy podzespołów są weryfikowane w toku prac doświadczalnych, celem sprawdzenia jakości nowych produktów a także możliwości uzyskania najbardziej korzystnych parametrów (np. w zakresie jakości materiałów, współdziałania elementów podzespołów). W pracach tych odkrywane są często nowe właściwości elementów, pojawiają się także nowe możliwości zastosowania innych rozwiązań oraz możliwości poznania nowych właściwości danej struktury.

Kolejnym etapem są prace konstrukcyjne prowadzące do budowy nowego produktu. Podlegają one kolejnym badaniom dotyczącym sprawności jego funkcjonowania i możliwości osiągania założonych funkcji i związanych z nimi efektów technicznych, ekonomicznych, czy społecznych ${ }^{3}$.

Pozytywne wyniki pozwalają na podejmowanie produkcji w skali półtechnicznej, polegającej na wytworzeniu gotowego produktu, który jako pewna całość poddany jest dalszym pracom doświadczalnym w warunkach do których jest przygotowywany dany wyrób.

Zadowalające wyniki prac pozwalają na uruchomienie produkcji danego wyrobu w skali technicznej i skierowanie go na rynek, celem dalszego sprawdzania jego własności i użyteczności. Ocena ta pozwala na określenie jego konkurencyjności oraz możliwości pogłębiania i rozszerzania rynku .

3 Przygotowanie nowej produkcji wymaga dużych nakładów finansowych, np. w fabryce Opla w Gliwicach na przygotowanie produkcji nowego modelu samochodu Cascady na bazie Astry wydano 55 mln euro (A. Woźniak, „Nowy Opel wyjedzie z Gliwic”, Rzeczpospolita, 28 lutego 2013 r.).

${ }^{4}$ W skierowanym na rynek nowym samolocie Boeinga - „Dreamliner” (model B-787), w trakcie eksploatacji stwierdzono wady, które związane są z przegrzewającymi się akumulatorami. W konsekwencji Federal 
Końcowym etapem jest produkcja masowa, która umożliwia kierowanie wyrobów gotowych na rynek. Ważnym zagadnieniem jest dalsza obserwacja jego chłonności a także możliwości rozszerzania ${ }^{5}$. W wyniku wypracowania bardzo skutecznych technik marketingowych dostosowanych do zróżnicowanej przestrzennie jakości klientów, globalne korporacje stały się bezkonkurencyjne. W stosunku do mniejszych producentów dysponują one znacznymi środkami finansowymi, które przeznaczają na reklamę swoich produktów do której wynajmują zazwyczaj znane osoby (najczęściej aktorów, sportowców, lekarzy). W odpowiednio sugestywny sposób przekonują oni potencjalnych klientów, którzy w konsekwencji wybierają masowo reklamowany produkt, czy usługę. Kształtowanie nowego rynku wspomagają także działania lobbingowe, które poprzez promowanie nowych produktów eliminują konkurencję i przyczyniają się do upadku konkurencyjnych wytwórców.

W wyniku mechanizmu rynkowego dany produkt generuje określone dochody ze sprzedaży, które zasilają źródła finansowania korporacji i umożliwiają dalsze finansowanie badań, których ostatecznym celem jest wprowadzenie na rynek nowych, technicznie bardziej zaawansowanych, skuteczniejszych i bardziej konkurencyjnych produktów. Podstawowym kryterium wyboru kierunków finansowania badań i wytwarzania nowych produktów jest rachunek ekonomiczny i przewidywana efektywność zainwestowanego kapitału.

Znaczącą rolę w tym zakresie odgrywają decydenci, którzy w oparciu o przyjęte strategie rozwoju przeznaczają odpowiednie środki na badania podstawowe, które aktywizują pozostałe etapy działalności.

Zarysowany mechanizm może być pobudzany lub hamowany przez otoczenie biznesowe, reprezentowane przez instrumenty prawne, postawy społeczne pobudzające rozwój przedsiębiorczości, tworzenie odpowiedniego klimatu wokół przedsiębiorców a także sprawność i poziom kwalifikacji zawodowych oraz mentalnych przedstawicieli otoczenia instytucjonalnego i zachowania elit ${ }^{6}$.

Tworzą one podstawy kreowania polityki prorozwojowej, umożliwiającej tworzenie korzystnych warunków wzrostu gospodarczego, społecznego i kulturowego, które

Aviation Administration zawiesił możliwość wykonywania lotów na wielu liniach, które zakupiły już 50 samolotów (w tym polski przewoźnik LOT). Niesprawność dostarczonych samolotów zmusiła przewoźników do ograniczenia tras, np. japońskie linie musiały zawiesić ponad 1,7 tys. połączeń, a LOT, aby utrzymać linie, będzie musiał wypożyczyć przynajmniej dwa samoloty (D. Walewska, „Dreamliner nie szybko znów wzniesie się w powietrze”, Rzeczpospolita, 28 lutego 2013 r.).

5 Według oceny kanadyjskiego Scotiabank zdolność produkcyjna europejskich fabryk samochodów sięga 18 mln sztuk. Aby zakłady mogły być rentowne ich moce produkcyjne muszą być wykorzystane w około $80 \%$. Rynek w latach obecnego kryzysu nie jest w stanie wchłonąć całej produkcji, stąd europejskie fabryki mają nadprodukcję około 3,6 mln sztuk pojazdów - to tyle, ile wynosi produkcja przynajmniej 12 fabryk. W konsekwencji w latach 2011-2012 wielkość produkcji samochodów w gliwickim Oplu zmniejszyła się ze 174 tys. szt. do 125 tys. szt. (A. Woźniak, „Nowy Opel wyjedzie z Gliwic”, Rzeczpospolita, 28 lutego 2013 r.).

${ }^{6}$ Według opinii polskich przedsiębiorców najpoważniejszymi barierami w zakresie prowadzenia firm są: skomplikowane procedury, na które wskazywało 35\% badanych, a następnie niejasne prawo (33\%), zły system podatkowy (29\%), wysokie koszty pracy (16\%), wysokie koszty finansowania (14\%), brak dostępu do finansowania (11\%) i in. (M. Bednarek, ,Kryzys (nie)straszny polskim firmom”, Gazeta Wyborcza, 15 listopada 2011 r.). 
w nawiązaniu do zróżnicowania elementów przestrzeni geograficznej prowadzą do rozwoju przestrzennego ${ }^{7}$.

W warunkach nasilających się procesów globalizacji rozwija się w gospodarce system korporacyjny. W nawiązaniu do procesu koncentracji kapitału kształtują się coraz potężniejsze korporacje międzynarodowe, które poprzez różnorodne działania prowadzą do internacjonalizacji produkcji. Poszczególne fabryki poprzez systemy zarządzania i związane z nimi powiązania kapitałowe, produkcyjne i organizacyjne stają się elementami bardziej złożonej struktury, którą steruje zarząd korporacji.

Zarząd korporacji w oparciu o kryteria efektywności i kierunki rozwoju gospodarczego i społecznego buduje określone strategie zachowania korporacji oraz przypisuje określone zadania poszczególnym elementom strukturalnym. Wyznacza on zadania: poszczególnym jednostkom naukowym, badawczo-rozwojowym, oddziałom produkcyjnym wytwarzającym gotowe produkty, czy podzespoły, określa kierunki kształtowania powiązań kooperacyjnych, dostawy surowców, materiałów i energii a także działań marketingowych. Wymienione elementy strukturalne korporacji mogą być rozmieszczone w wielu krajach a nasilenie powiązań zachodzących między nimi wyznaczają kierunki i wielkości strumieni finansowych i kapitałowych wynikających ze stosowanych metod zarządzania oraz założonych celów strategicznych korporacji. Podstawowym kryterium wyboru ich lokalizacji może być możliwość obniżenia kosztów produkcji dzięki taniej sile roboczej, atrakcyjność nowych miejsc lokalizacji, występowanie wykształconych zasobów pracy, możliwość obserwowania zmieniającej się sytuacji rynkowej, stopień stabilizacji sceny politycznej i in.

W procesie tym ważną rolę odgrywa rynek pracy, który wpływa na określony stopień mobilności jego zasobów. Niskie koszty pracy są bardzo korzystnym czynnikiem lokalizacji działalności gospodarczej w różnych układach przestrzennych poza siedzibą zarządu. Wpływają one na przenoszenie tych segmentów produkcji (zwłaszcza montażowej), które wymagają znacznej liczby pracowników. Otrzymują oni z reguły niższe zarobki aniżeli pracownicy w kraju macierzystym a nadto nie korzystają ze świadczeń społecznych związanych z ich rodzinami, nie stwarzają konkurencji na rynku pracy itp ${ }^{8}$. Równocześnie kraje o najwyższych zarobkach wpływają na ich dużą atrakcyjność dla migracji potencjalnych pracowników.

7 Jako przykład może służyć rynek żarówek. Pod pozorem oszczędności energii zakazano używania tradycyjnych żarówek w UE i na rynku pozostały tylko firmy, które posiadają technologię produkcji żarówek energooszczędnych. „Der Spiegel” opisał to jako atak na demokrację. Magazyn „EuroActiv” szacuje, że w Brukseli jest ok. 15 tys. instytucji dbających o interesy swoich sektorów lub firm, a liczba ekspertów w całej UE, którzy angażują się w tworzenie regulacji korzystnych dla danej grupy interesów przekracza 500 tys. (K. Rybiński, „Rynek bezkonkurencyjny”, PlusMinus, 1-2 grudnia 2012 r.). Równocześnie wysoki stopień fiskalizmu, prowadzi do niekorzystnych zjawisk przejawiających się w ucieczce podatników (korporacji, czy bogatej części społeczeństwa) do tzw. rajów podatkowych (m.in. Wyspy Bahama, Kajmany, Bermudy, Jersey, Wyspy Dziewicze, Gibraltar, Cypr, Lichtenstein, Angora, Singapur). Np. na Cyprze działa około 1,7 tys. firm doradczych podatkowych, a w strukturze PKB tego kraju 60,1\% stanowi pośrednictwo finansowe, 23,7\% handel i 13,7\% nieruchomości (D. Walewska, „,Raj na skrzyżowaniu szlaków", Rzeczpospolita (Eko+), 6 maja 2011 r.).

${ }^{8}$ Koszt godziny pracy w Unii Europejskiej waha się od 39,3 euro do 3,5 euro, przy średniej unijnej 23,1 euro. Najwyższe płace za godzinę pracy są w Belgii (39,3 euro), Francji (34,2 euro), Niemczech (30,1 euro), Austrii 29,2 euro), natomiast najniższe w Polsce (7,1 euro), na Łotwie (5,9 euro), na Litwie (5,5 euro) i w Bułgarii (3,5 euro). Należy jednak zaznaczyć, że udział podatków i składek w średnich zarobkach wynosi w Belgii 55,5\%, w Niemczech 49,8\%, we Francji 49,4\%, podczas gdy w Polsce 34,5\% a w Nowej Zelandii 15,9\% i w Chile 7,0\%, (L. Kostrzewski, P. Mączyński, „Praca za droga? To mit”, Gazeta Wyborcza, 20-21 października 2012 r.). Zdaniem 
NAKŁADY FINANSOWE NA DZIAŁALNOŚĆ BADAWCZO-ROZWOJOWĄ DOMINUJĄCYCH KORPORACJI

Proces wdrażania nowych produktów oraz ich konkurencyjność na rynku w zasadniczym stopniu stymulują decyzje zarządów korporacji, które m.in. określają wielkość nakładów finansowych na badania i rozwój. Rozmiary finansowania prac badawczo-rozwojowych przez zarządy przedsiębiorstw w zasadniczym stopniu związane są z ich potencjałem ekonomicznym oraz dążeniem do podnoszenia pozycji konkurencyjnej oferowanych produktów na rynku.

Systematyczne dążenie do podnoszenia pozycji konkurencyjnej oferowanych produktów wymaga od zarządów przedsiębiorstw przeznaczania znacznych kwot na badania i rozwój. W 2004 r. wśród firm światowych największe wydatki na ten cel poniosła korporacja DaimlerChrysler - 5,7 mld dol., Pfizer - 5,7 mld dol. i Ford Motor - 5,4 mld dol. Natomiast gdyby traktować Polskę jako firmę, jej wydatki na ten cel uplasowały by ją w strukturze rangowej na 64 pozycji ${ }^{9}$.

W 2010 r. wśród korporacji światowych dominujące znaczenie pod względem wartości środków finansowych przeznaczonych na prace badawczo-rozwojowe miała korporacja Roche, która na ten cel przeznaczyła 7,2 mld euro, drugą pozycję zajmuje korporacja Pfizer, która przeznaczyła 7,0 mld euro a następną Microsoft - 6,7 mld. Na następnych miejscach plasują się Toyota Motor - 6,7 mld dol., Merck US - 6,4 mld dol., Volkswagen - 6,3 mld dol. i Samsung Electric - 6,1 mld dol. (tab. 1). Natomiast w tym czasie Polska przeznaczyła na ten cel 1,5 mld dol. i w strukturze światowych korporacji znalazłaby się przed korporacją BASF, która zajmuje 70 miejsce i za Procter\&Gamble zajmującą 71 pozycję ${ }^{10}$.

W latach kryzysu gospodarczego nakłady finansowe na badania i rozwój odznaczają się różnymi tendencjami. Biorąc jako kryterium dynamikę nakładów na ten cel można wyróżnić korporacje, które: nie zareagowały na kryzys i odznaczały się systematycznym wzrostem nakładów na badania i rozwój; odznaczające się systematycznym spadkiem nakładów, czy spadkiem nakładów tyko w 2009 roku w związku z nasilającym się kryzysem gospodarczym.

Na kryzys nie zareagowały korporacje, które w latach 2008-2010 charakteryzowały się systematycznym wzrostem nakładów na badania i rozwój. Grupę tę reprezentują m.in. Oracle (która systematycznie zwiększała nakłady na ten cel z 0,9\% w 2008 r. i 17,6\% w 2009 r. do 38,9\% w 2010 r.), General Electric (która w tych latach zwiększała nakłady odpowiednio z $0,4 \%$ i 10,1\% do 18,05\%) i Novatis $(5,6 \%, 7,6 \%, 10,9 \%)$. Abbott Laboratories zwiększył nakłady z 7,3\% w 2008 r. do 35,7\% w 2010 r. Reprezentują one korporacje Stanów

$\overline{\text { R. Petru nasza przewaga wynika głównie z niskich kosztów pracy ale pod tym względem rośnie nam konkurencja ze }}$ strony Bułgarii i Rumunii. ,Jeżeli chcemy być atrakcyjnym miejscem dla inwestorów z zagranicy, musimy zacząć konkurować większą wydajnością pracy”. Jego zdaniem na naszą niekorzyść działają: wciąż opieszałe sądownictwo, ogrom biurokracji, nieprzewidywalność przepisów podatkowych i słaba jakość usług publicznych (J. Mysior, „Inwestorzy: Polska wicemistrzem Europy”, Gazeta Wyborcza, 22 czerwca 2012 r.).

${ }^{9}$ Monitoring Industrial Research, grudzień 2005, za: Gazeta Wyborcza, 21 grudnia 2006 r.

${ }^{10}$ K. Baca-Podgorzelska, „Polska najmniej innowacyjna w Unii”, Rzeczpospolita, 19 września 2012 r. 
Zjednoczonych, Niemiec, Szwajcarii, Szwecji, które są związane z oprogramowaniem, telekomunikacją, farmacją i lotnictwem.

Kryzys w najpoważniejszym stopniu wpłynął na zmniejszenie nakładów w korporacjach przemysłu samochodowego (Ford Motor w 2009 r. zmniejszył nakłady o 32,9\%, General Motor o 24,2\%) a także koncernach farmaceutycznych (Merck US o 21,6\%, Eli Lilly o 32,9\%) oraz firmach takich jak AstraZeneca, Ericsson, Canon, BMW i Alcatel-Lucent.

Tab. 1. Nakłady finansowe na badania i rozwój dominujących korporacji w 2010 r.

\begin{tabular}{|c|c|c|c|c|c|c|c|}
\hline \multirow{2}{*}{ Rank } & \multirow{2}{*}{ Korporacje } & \multirow{2}{*}{ Sektory } & \multirow{2}{*}{ Kraje } & \multicolumn{3}{|c|}{$\begin{array}{c}\text { Dynamika (rok } \\
\text { poprzedni }=100 \text { ) }\end{array}$} & \multirow{2}{*}{$\begin{array}{c}2010 \\
\text { w mln } \\
\text { dol. }\end{array}$} \\
\hline & & & & 2008 & 2009 & 2010 & \\
\hline 1. & Roche & Farmacja & Szwajcaria & 4,6 & 8,3 & $-4,5$ & 7181,11 \\
\hline 2. & Pfizer & Farmacja & USA & $-1,8$ & $-2,4$ & 21,4 & 7016,61 \\
\hline 3. & Microsoft & Oprogramowanie & USA & 10,4 & $-3,3$ & 3,8 & 6740,81 \\
\hline 4. & Toyota Motor & Samochody & Japonia & 7,6 & $-5,7$ & $-19,4$ & 6666,69 \\
\hline 5. & Merck US & Farmacja & USA & 64,2 & 21,6 & 47,0 & 6403,88 \\
\hline 6. & Volkswagen & Samochody & Niemcy & 20,4 & 2,3 & 8,1 & 6258,00 \\
\hline 7. & $\begin{array}{l}\text { Samsung } \\
\text { Electronics }\end{array}$ & Elektronika & Korea Płd. & 14,8 & 8,0 & 24,9 & 6181,36 \\
\hline 8. & Novartis & Farmacja & Szwajcaria & 5,6 & 7,6 & 10,9 & 6022,97 \\
\hline 9. & General Motors & Samochody & USA & $-1,2$ & $-24,2$ & 14,7 & 5189,60 \\
\hline 10. & Johnson\&Johnson & Farmacja & USA & $-1,3$ & $-7,8$ & $-2,0$ & 5101,64 \\
\hline 11. & Nokia & Telekomunikacja & Finlandia & 0,8 & $-6,1$ & $-1,2$ & 4938,00 \\
\hline 12. & Intel & Telekomunikacja & Finlandia & $-0,6$ & $-1,2$ & 16,3 & 4901,87 \\
\hline 13. & Daimler & Samochody & Niemcy & $-9,2$ & $-6,2$ & 16,5 & 4852,00 \\
\hline 14. & Sanofi Aventis & Farmacja & Francja & 0,9 & 0,2 & $-3,9$ & 4390,00 \\
\hline 15. & Panasonic & $\begin{array}{l}\text { Produkty rekrea- } \\
\text { cyjne }\end{array}$ & Japonia & $-4,1$ & $-6,6$ & $-7,9$ & 4383,25 \\
\hline 16. & GlaxoSmithKline & Farmacja & $\begin{array}{l}\text { Wielka } \\
\text { Brytania }\end{array}$ & 5,3 & 9,5 & 3,4 & 4378,25 \\
\hline 17. & Honda Motor & Samochody & Japonia & 6,5 & $-4,2$ & $-17,7$ & 4258,72 \\
\hline 18. & Siemens & Elektryczny & Niemcy & 10,8 & 1,9 & $-1,0$ & 4241,00 \\
\hline 19. & Sony & Elektroniczny & Japonia & $-4,3$ & $-4,5$ & $-13,1$ & 3970,55 \\
\hline 20. & Cisco Systems & Telekomunikacja & USA & 14,5 & 1,1 & 1,2 & 3930,59 \\
\hline 21. & Robert Bosch & Motoryzacja & Niemcy & 10,0 & $-8,6$ & 6,9 & 3824,00 \\
\hline 22. & IBM & Komputery & USA & 3,7 & $-9,39$ & 2,8 & 3788,21 \\
\hline 23. & Ford Motor & Samochody & USA & $-2,7$ & $-32,9$ & 2,0 & 3727,09 \\
\hline 24. & Eli Lilly & Farmacja & USA & 10,2 & $-32,9$ & 12,9 & 3640,77 \\
\hline 25. & Nissan Motor & Samochody & Japonia & $-1,6$ & $-0,4$ & $-15,4$ & 3542,75 \\
\hline 26. & Hitachi & Komputery & Japonia & 3,8 & $-2,7$ & $-10,6$ & 3423,40 \\
\hline
\end{tabular}




\begin{tabular}{|l|l|l|l|r|r|r|r|}
\hline 27. & Oracle & Oprogramowanie & USA & 0,9 & 17,6 & 38,9 & 3368,54 \\
\hline 28. & Bayer & Chemiczny & Niemcy & 3,0 & 8,8 & 8,3 & 3211,00 \\
\hline 29. & AstraZeneca & Farmacja & $\begin{array}{l}\text { Wielka } \\
\text { Brytania }\end{array}$ & 1,4 & $-12,0$ & $-3,0$ & 3204,55 \\
\hline 30. & EADS & Lotnictwo & Niderlandy & 2 & 4,4 & 7,2 & 3084,00 \\
\hline 31. & Ericsson & Telekomunikacja & Szwecja & 10,4 & $-12,6$ & 11,5 & 3022,42 \\
\hline 32. & Toshiba & Ogólnoprzemysłowe & Japonia & $-0,2$ & $-3,8$ & $-14,5$ & 2970,99 \\
\hline 33. & General Electric & Ogólnoprzemysłowe & USA & 0,4 & 10,1 & 18,5 & 2936,20 \\
\hline 34. & Canon & Eletronika & Japonia & 1,6 & $-18,6$ & 3,7 & 2903,70 \\
\hline 35. & Boeing & Lotnictwo & USA & $-3,0$ & 0,9 & 8,5 & 2807,24 \\
\hline 36. & Google & Internet & USA & 31,8 & 1,8 & 32,3 & 2804,26 \\
\hline 37. & $\begin{array}{l}\text { Abbott } \\
\text { Laboratories }\end{array}$ & Farmacja & USA & 7,3 & 2,0 & 35,7 & 2776,25 \\
\hline 38. & BMW & Samochody & Niemcy & $-8,9$ & $-14,6$ & 13,3 & 2773,00 \\
\hline 39. & $\begin{array}{l}\text { Takeda } \\
\text { Pharmaceutical }\end{array}$ & Farmacja & Japonia & 42,7 & 64,3 & $-34,6$ & 2724,16 \\
\hline 40. & Bristol-Myers & Farmacja & USA & 9,2 & 1,7 & $-2,2$ & 2658,16 \\
\hline 41. & Alcatel-Lucent & Telekomunikacja & Francja & $-10,7$ & $-12,3$ & 5,1 & 2559,00 \\
\hline 42. & NTT & Telekomunikacja & Japonia & $-0,4$ & $-1,1$ & 3,7 & 2556,44 \\
\hline 43. & NEC & Komputery & Japonia & 5,2 & $-1,6$ & $-20,4$ & 2536,46 \\
\hline 44. & Denso & Motoryzacja & Japonia & 11,3 & $-4,6$ & $-9,1$ & 2482,30 \\
\hline 45. & $\begin{array}{l}\text { Boehringer } \\
\text { Ingelheim }\end{array}$ & Farmacja & Niemcy & 21,9 & 5,0 & 10,7 & 2453,00 \\
\hline
\end{tabular}

Źródło: European Commission. Monitoring industrial research

Systematycznie malejącymi nakładami charakteryzowały się głównie koncerny japońskie - Nissan Motor (którego nakłady na ten cel spadały o 1,6\% w 2008 r., o 4\% w 2008 r. i o 15,4\% w 2010 r.), Sony (odpowiednio 4,3\%, 4,5\%, 13,1\%), NEC (przy wzroście o 5,2\% w 2008, nastąpił spadek o 20,4\% w 2010 r.), Toyota Motor (przy wzroście w 2008 r. o 7,6\% zaznaczył się spadek o 19,4\% w 2010 r.). Podobnymi zachowaniami odznaczają się korporacje Siemens, Cisco Systems, Johnson\&Johnson, Panasonic, Nissan Motor, Toshiba i in.

W niektórych korporacjach wpływ kryzysu zaznaczył się już w latach 2008-2009, kiedy to nakłady na prace badawczo-rozwojowe zmniejszały się (np. Pfizer, Intel, Daimler, BMW). W innych wystąpił dopiero w latach 2009-2010 lub tylko w 2009 r.

NAKŁADY NA BADANIA I ROZWÓJ WEDŁUG SEKTORÓW GOSPODARKI W 2010 R.

W 2010 r. nakłady na badania i rozwój 1400 dominujących światowych korporacji wynosiły 456,9 mld dol. (tab. 2). Wśród nich łącznie najwyższymi nakładami na badania i rozwój charakteryzuje się 89 korporacji przemysłu farmaceutycznego, które obejmują 6,36\% 
ich ogólnej liczebności a przeznaczają na ten cel 77,8 mld dol., tj. 17,07\% ogólnych nakładów. Kolejną pozycję zajmuje 90 korporacji przemysłu samochodowego, które obejmują 6,43\% korporacji i 15,04\% ogólnych nakładów. Łącznie te dwa sektory obejmują 12,79\% ogólnej liczby korporacji i obejmują 32,11\% ogólnych nakładów.

Tab. 2. Nakłady finansowe na badania i rozwój światowych korporacji według sektorów w $2010 \mathrm{r}$.

\begin{tabular}{|c|c|c|c|c|c|}
\hline Ogółem sektory* & $\begin{array}{c}\text { Liczba kor- } \\
\text { poracji }\end{array}$ & $\begin{array}{l}\text { Wartość } \\
\text { nakładów }\end{array}$ & $\begin{array}{c}\text { Udział kor- } \\
\text { poracji }\end{array}$ & $\begin{array}{c}\text { Udział } \\
\text { nakładów }\end{array}$ & $\begin{array}{l}\text { Przeciętne } \\
\text { nakłady na } \\
\text { korporację }\end{array}$ \\
\hline Ogólem & 1400 & 455966,44 & 100,00 & 100,00 & 325,7 \\
\hline Pharmaceuticals (4577) & 89 & 77819,96 & 6,36 & 17,07 & 874,4 \\
\hline Automobiles \& parts (335) & 90 & 68572,30 & 6,43 & 15,04 & 761,9 \\
\hline Semiconductors (9576) & 122 & 28189,56 & 8,71 & 6,18 & 231,1 \\
\hline $\begin{array}{l}\text { Telecommunications equipment } \\
\text { (9578) }\end{array}$ & 60 & 27435,88 & 4,29 & 6,02 & 457,3 \\
\hline Software (9537) & 82 & 21632,01 & 5,86 & 4,74 & 263,8 \\
\hline Electronic equipment (2737) & 65 & 20824,39 & 4,64 & 4,57 & 320,4 \\
\hline Chemicals (135) & 89 & 20183,79 & 6,36 & 4,43 & 226,8 \\
\hline Aerospace \& defence (271) & 44 & 16153,45 & 3,14 & 3,54 & 367,1 \\
\hline Leisure goods (374) & 29 & 14480,13 & 2,07 & 3,18 & 499,3 \\
\hline Computer hardware (9572) & 43 & 14000,95 & 3,07 & 3,07 & 325,6 \\
\hline General industrials (272) & 43 & 13666,46 & 3,07 & 3,00 & 317,8 \\
\hline Computer services (9533) & 25 & 10495,24 & 1,79 & 2,30 & 419,8 \\
\hline $\begin{array}{l}\text { Electrical components } \\
\text { \& equipment (2733) }\end{array}$ & 34 & 10055,43 & 2,43 & 2,21 & 295,7 \\
\hline Biotechnology (4573) & 57 & 9485,12 & 4,07 & 2,08 & 166,4 \\
\hline $\begin{array}{l}\text { Health care equipment } \\
\& \text { services (453) }\end{array}$ & 58 & 9364,35 & 4,14 & 2,05 & 161,5 \\
\hline $\begin{array}{l}\text { Fixed line telecommunications } \\
(653)\end{array}$ & 18 & 9077,38 & 1,29 & 1,99 & 504,3 \\
\hline $\begin{array}{l}\text { Commercial vehicles \& trucks } \\
(2753)\end{array}$ & 27 & 7940,36 & 1,93 & 1,74 & 294,1 \\
\hline Oil \& gas producers (53) & 22 & 7887,43 & 1,57 & 1,73 & 358,5 \\
\hline Industrial machinery (2757) & 74 & 7807,39 & 5,29 & 1,71 & 105,5 \\
\hline Banks (835) & 23 & 6511,31 & 1,64 & 1,43 & 283,1 \\
\hline Food producers $(357)$ & 32 & 6324,68 & 2,29 & 1,39 & 197,6 \\
\hline $\begin{array}{l}\text { Electronic office equipment } \\
\text { (9574) }\end{array}$ & 8 & 6146,34 & 0,57 & 1,35 & 768,3 \\
\hline Construction \& materials (235) & 34 & 4868,73 & 2,43 & 1,07 & 143,2 \\
\hline Internet (9535) & 13 & 4422,54 & 0,93 & 0,97 & 340,2 \\
\hline $\begin{array}{l}\text { Household goods \& home con- } \\
\text { struction }(372)\end{array}$ & 23 & 4056,84 & 1,64 & 0,89 & 176,4 \\
\hline
\end{tabular}




\begin{tabular}{|l|r|r|r|r|r|}
\hline Industrial metals \& mining (175) & 23 & 3228,53 & 1,64 & 0,71 & 140,4 \\
\hline Electricity (753) & 20 & 3154,86 & 1,43 & 0,69 & 157,7 \\
\hline Media (555) & 13 & 2964,99 & 0,93 & 0,65 & 228,1 \\
\hline General retailers (537) & 8 & 2821,25 & 0,57 & 0,62 & 352,7 \\
\hline Personal goods (376) & 22 & 2684,39 & 1,57 & 0,59 & 122,0 \\
\hline $\begin{array}{l}\text { Oil equipment, services \& distri- } \\
\text { bution (57) }\end{array}$ & 13 & 2061,70 & 0,93 & 0,45 & 158,6 \\
\hline Travel \& leisure (575) & 15 & 1611,94 & 1,07 & 0,35 & 107,5 \\
\hline Support services (279) & 14 & 1490,75 & 1,00 & 0,33 & 106,5 \\
\hline Beverages (353) & 5 & 1132,57 & 0,36 & 0,25 & 226,5 \\
\hline Mining (177) & 7 & 1122,42 & 0,50 & 0,25 & 160,3 \\
\hline Tobacco (378) & 5 & 1119,26 & 0,36 & 0,25 & 223,9 \\
\hline Gas, water \& multiutilities (757) & 8 & 1010,37 & 0,57 & 0,22 & 126,3 \\
\hline Food \& drug retailers (533) & 6 & 880,73 & 0,43 & 0,19 & 146,8 \\
\hline Mobile telecommunications (657) & 4 & 760,99 & 0,29 & 0,17 & 190,2 \\
\hline Alternative energy (58) & 8 & 700,02 & 0,57 & 0,15 & 87,5 \\
\hline Other financials (877) & 10 & 620,19 & 0,71 & 0,14 & 62,0 \\
\hline Forestry \& paper (173) & 5 & 350,49 & 0,36 & 0,08 & 70,1 \\
\hline Nonlife insurance (853) & 3 & 293,28 & 0,21 & 0,06 & 97,8 \\
\hline Life insurance (857) & 3 & 291,55 & 0,21 & 0,06 & 97,2 \\
\hline Industrial transportation (277) & 4 & 264,13 & 0,29 & 0,06 & 66,0 \\
\hline
\end{tabular}

* W tabeli podano oryginalne nazwy sektorów wg The Industry Classification Benchmark (ICB)

Źródło: European Commission. Monitoring industrial research

Trzecią pozycję zajmują najliczniej występujące w tej zbiorowości 122 korporacje reprezentujące sektor półprzewodników, które stanowią 8,71\% korporacji i obejmują $6,18 \%$ ogólnych nakładów. Kolejną pozycję zajmują korporacje sektora telekomunikacji reprezentowane przez 60 korporacji obejmujących 6,02\% ogólnych nakładów. Łącznie stanowią one 14,14\% ogólnej liczby korporacji i obejmują 12,2\% nakładów na badania i rozwój.

Łącznie te cztery sektory w zakresie nakładów finansowych na badania i rozwój odgrywają dominującą rolę w strukturze światowych korporacji. Reprezentują one $25,79 \%$ ich ogólnej liczby i obejmują 44,31\% ogólnych nakładów.

Kolejne pozycje zajmują sektory: urządzeń telekomunikacyjnych, oprogramowania, urządzeń elektronicznych, przemysłu chemicznego, lotniczego i sprzętu komputerowego, obejmujące od 3,0\% do 4,0\% ogólnych nakładów.

Można przyjąć, że wymienione sektory w strukturze przemysłu i gospodarki światowej w najpoważniejszym stopniu pobudzają rozwój technologiczny, przyśpieszają procesy kształtowania społeczeństwa informacyjnego oraz wdrażania gospodarki opartej na wiedzy a także nasilają procesy globalizacji. Łącznie obejmują one 54,0\% analizowanych korporacji światowych, które łącznie na badania i rozwój przeznaczyły 70,8\% ogólnych nakładów. 
Poszczególne sektory gospodarki poważnie różnicują się pod względem przeciętnej wartości nakładów przypadających na korporację. Obserwujemy tu duże różnice wahające się od 66,0 mld dol. w przemyśle transportowym do 874,4 mld w przemyśle farmaceutycznym. Najwyższymi przeciętnymi nakładami charakteryzuje się przemysł farmaceutyczny (874,4 mld dol.), elektronicznych urządzeń wyposażenia biur (768,3 mld dol.), przemysł samochodowy (761,9 mld dol.) i budowy linii telekomunikacyjnych (504,3 mld dol.). Można więc przyjąć, że sektory te są najbardziej naukochłonne, a ich osiągnięcia niewątpliwie stawać się będą coraz trudniej dostępne dla tych mniejszych przedsiębiorstw gospodarczych zlokalizowanych na terenie innych krajów. Wpływać będą na nasilanie się procesów konsolidacji i przejęć podobnych przedsiębiorstw w skali światowej, które narastać będzie wraz z wychodzeniem z kryzysu gospodarczego.

\section{NAKŁADY NA BADANIA I ROZWÓJ WEDŁUG SIEDZIB ZARZĄDÓW KORPORACJI}

W światowej przestrzeni ekonomicznej występują bardzo zróżnicowane warunki dla rozwoju dominujących korporacji o znaczeniu międzynarodowym. Podstawową rolę w strukturze korporacji odgrywają ich zarządy, które podejmują wszelkie decyzje dotyczące strategii rozwoju korporacji a w tym: określania rozmiarów i asortymentu produkcji, nowych lokalizacji, nakładów finansowo-kapitałowych, przepływu technologii, programowania nowych kierunków rozwoju produkcji i jego asortymentu a także nakładów na prace badawczo-rozwojowe. Podejmując określone decyzje należy pamiętać, że podstawowym kryterium podejmowanych działań jest dążenie do maksymalizacji zysków, czy minimalizacji nakładów, chęć dominacji na rynku oraz podnoszenia konkurencyjności oferowanych produktów. Natomiast wykonawcami założonych działań są różnego rodzaju oddziały produkcyjne, usługowe, kooperacyjne, finansowe, marketingowe występujące na terenie poszczególnych krajów $^{11}$.

Siedziby dominujących korporacji pod względem nakładów na badania i rozwój znajdują się na terenie 43 krajów. Wśród nich dominujące znaczenie mają Stany Zjednoczone na terenie których występuje 487 siedzib zarządów korporacji, tj. 34,8\% ich liczebności, które skupiają 35,1\% ogólnych nakładów na badania i rozwój (tab. 3). Drugą pozycję zajmuje Japonia na terenie której występuje 19,1\% siedzib zarządów, których udział w tym zakresie wynosi 21,7\%. Oznacza to, że te dwa kraje odgrywają obecnie rolę światowych biegunów wzrostu technologicznego i naukowego, koncentrując łącznie na swoim terenie 53,9\% siedzib zarządów, które przeznaczyły na badania i rozwój 56,8\% nakładów finansowych.

${ }^{11}$ W strukturze organizacyjnej korporacji Motorola w 2000 r. występowało 928 filii i oddziałów zlokalizowanych w 66 krajach w 401 miastach, przy czym najwięcej z nich zlokalizowanych jest na terenie obu Ameryk (50,2\%), Azji i Oceanii (26,3\%) i w Europie (19,3\%), a najmniej na terenie Afryki (0,65\%) (Wajda 2003). Korporacja Nokia miała swoje oddziały zlokalizowane na terenie 52 krajów, w tym 13 na terenie Stanów Zjednoczonych i po 7 w Brazylii, Wielkiej Brytanii i Chinach (Wajda 2006). 
Tab. 3. Nakłady finansowe na badania i rozwój światowych korporacji według krajów w 2010 r.

\begin{tabular}{|c|c|c|c|c|c|}
\hline Kraje & $\begin{array}{l}\text { Liczba } \\
\text { korporacji }\end{array}$ & $\begin{array}{l}\text { Wartość nakładów } \\
\text { w mln dol. }\end{array}$ & $\begin{array}{c}\text { Udział } \\
\text { korporacji }\end{array}$ & $\begin{array}{c}\text { Udział } \\
\text { nakładów }\end{array}$ & $\begin{array}{l}\text { Przeciętne nakłady } \\
\text { na korporację }\end{array}$ \\
\hline Ogólem & 1400 & 455966,4 & 100,00 & 100,00 & 325,7 \\
\hline Stany Zjednoczone & 487 & 160121,9 & 34,79 & 35,12 & 328,8 \\
\hline Japonia & 267 & 99084,8 & 19,07 & 21,73 & 371,1 \\
\hline Niemcy & 101 & 46248,3 & 7,21 & 10,14 & 457,9 \\
\hline Francja & 58 & 24245,6 & 4,14 & 5,32 & 418,0 \\
\hline Szwajcaria & 40 & 20670,6 & 2,86 & 4,53 & 516,8 \\
\hline Wielka Brytania & 79 & 20091,8 & 5,64 & 4,41 & 254,3 \\
\hline Korea Południowa & 25 & 13494,7 & 1,79 & 2,96 & 539,8 \\
\hline Holandia & 21 & 9471,9 & 1,50 & 2,08 & 451,0 \\
\hline Chiny & 19 & 7631,8 & 1,36 & 1,67 & 401,7 \\
\hline Tajwan & 50 & 7500,0 & 3,57 & 1,64 & 150,0 \\
\hline Szwecja & 24 & 7057,6 & 1,71 & 1,55 & 294,1 \\
\hline Włochy & 23 & 6433,7 & 1,64 & 1,41 & 279,7 \\
\hline Finlandia & 14 & 5744,7 & 1,00 & 1,26 & 410,3 \\
\hline Dania & 24 & 3711,5 & 1,71 & 0,81 & 154,6 \\
\hline Hiszpania & 14 & 3481,1 & 1,00 & 0,76 & 248,7 \\
\hline Australia & 12 & 2371,0 & 0,86 & 0,52 & 197,6 \\
\hline Irlandia & 10 & 2076,5 & 0,71 & 0,46 & 207,7 \\
\hline Kanada & 12 & 1887,2 & 0,86 & 0,41 & 157,3 \\
\hline Indie & 18 & 1856,2 & 1,29 & 0,41 & 103,1 \\
\hline Brazylia & 9 & 1819,7 & 0,64 & 0,40 & 202,2 \\
\hline Belgia & 12 & 1744,6 & 0,86 & 0,38 & 145,4 \\
\hline Bermudy & 4 & 1400,3 & 0,29 & 0,31 & 350,1 \\
\hline Izrael & 9 & 1274,2 & 0,64 & 0,28 & 141,6 \\
\hline Hong Kong & 8 & 1023,7 & 0,57 & 0,22 & 128,0 \\
\hline Norwegia & 9 & 914,0 & 0,64 & 0,20 & 101,6 \\
\hline Kajmany & 12 & 827,0 & 0,86 & 0,18 & 68,9 \\
\hline Rosja & 2 & 679,4 & 0,14 & 0,15 & 339,7 \\
\hline Austria & 8 & 582,4 & 0,57 & 0,13 & 72,8 \\
\hline Luksemburg & 4 & 529,1 & 0,29 & 0,12 & 132,3 \\
\hline Singapur & 6 & 468,1 & 0,43 & 0,10 & 78,0 \\
\hline Portugalia & 3 & 294,5 & 0,21 & 0,06 & 98,2 \\
\hline Turcja & 4 & 272,0 & 0,29 & 0,06 & 68,0 \\
\hline Lichtenstein & 1 & 189,2 & 0,07 & 0,04 & 189,2 \\
\hline
\end{tabular}




\begin{tabular}{|l|c|c|c|c|c|}
\hline Węgry & 2 & 139,7 & 0,14 & 0,03 & 69,9 \\
\hline Arabia Saudyjska & 1 & 129,7 & 0,07 & 0,03 & 129,7 \\
\hline Południowa Afryka & 1 & 102,3 & 0,07 & 0,02 & 102,3 \\
\hline Słowenia & 1 & 90,9 & 0,07 & 0,02 & 90,9 \\
\hline Malezja & 1 & 64,8 & 0,07 & 0,01 & 64,8 \\
\hline Czechy & 1 & 61,6 & 0,07 & 0,01 & 61,6 \\
\hline Nowa Zelandia & 1 & 60,6 & 0,07 & 0,01 & 60,6 \\
\hline Tajlandia & 1 & 43,3 & 0,07 & 0,01 & 43,3 \\
\hline Islandia & 1 & 42,3 & 0,07 & 0,01 & 42,3 \\
\hline Grecja & 1 & 32,2 & 0,07 & 0,01 & 32,2 \\
\hline
\end{tabular}

Źródło: European Commission. Monitoring industrial research

Trzecią pozycję w świecie zajmują Niemcy, na terenie których zlokalizowanych jest 101 korporacji, tj. 7,2\% ogólnej liczby korporacji i obejmują 10,1\% nakładów na badania i rozwój. Kolejne pozycje zajmują: Francja, Szwajcaria, Wielka Brytania, Holandia, Szwecja, Hiszpania i Irlandia.

Stosunkowo małą rolę w tym zakresie odgrywają kraje pretendujące do nowych światowych biegunów wzrostu grupy BRICA (Brazylia, Rosja, Indie, Chiny, Afryka Południowa). $\mathrm{Na}$ ich terenie występuje 49 zarządów światowych korporacji, tj. 3,4\%, a ich udział w nakładach na prace badawczo-rozwojowe jest znacznie niższy i wynosi tylko 2,7\%. Wśród nich najpoważniejsze znaczenie mają Chiny, które skupiają 19 zarządów korporacji o udziale w nakładach na ten cel 1,67\%. Kraje te w mniejszym stopniu dotknął kryzys światowy, stąd należy wnosić, że ich udział w tym zakresie będzie systematycznie wzrastał. Wydaje się, że będzie to jeden z podstawowych warunków ich wzrostu gospodarczego.

Na obszarze poszczególnych krajów prowadzone są bardzo zróżnicowane pod względem kapitałochłonności badania, czego wyrazem jest przeciętna wartość nakładów na korporację, która waha się od 32,2 mln dol. do 539,8 tys. dol. Najbardziej kapitałochłonne badania prowadzone są na terenie Korei Południowej, gdzie na jedną korporację przypada 539,8 mln dol. i w Szwajcarii (516,8 mln dol.). Następnie od 400 do 500 tys. dol. przeznaczają średnio korporacje mające swoje zarządy na terenie: Chin, Finlandii, Szwajcarii, Francji, Holandii i Niemiec.

\section{UWAGI KOŃCOWE}

Przedstawione rozważania podkreślają jak dużą rolę przypisują zarządy światowych korporacji pracom badawczo-rozwojowym, dzięki którym mogą: rozwijać badania podstawowe w poszczególnych dyscyplinach naukowych, dążyć do poszukiwania idei nowych produktów, rozwijania prac projektowych, doświadczalnych i konstrukcyjnych. Dopiero odpowiedni stopień zaawansowania tych prac oraz ich efekty pozwalają na oferowanie 
konkurencyjnych produktów kierowanych na rynek a osiągane dochody zasilają źródła finansowania działalności korporacji. Przedstawione wartości nakładów na prace badawczo-rozwojowe poszczególnych światowych korporacji wskazują na bardzo duże zróżnicowanie w tym zakresie. Wynika to z różnej dynamiki rozwoju technologicznego i dbania o oferowanie nowoczesnych i konkurencyjnych na rynku produktów. Wpływają one w ten sposób na nasilanie procesów kształtowania gospodarki opartej na wiedzy i społeczeństwa informacyjnego. Szczególne znaczenie w tym zakresie mają silnie rozwijający się przemysł farmaceutyczny, samochodowy, chemiczny, lotniczy oraz nowo pojawiające się przemysły związane ze społeczeństwem informacyjnym (m.in. półprzewodniki, oprogramowanie, urządzenia telekomunikacyjne, produkcja i usługi komputerowe). Należy podkreślić, iż na te nowe sektory w najmniejszym stopniu wpłynął kryzys gospodarczy, czego wyrazem był systematyczny wzrost nakładów finansowych na badania i rozwój, natomiast najmocniej zaznaczył się w sektorze samochodowym, co związane jest częściowo z nadprodukcją samochodów oraz w korporacjach japońskich, na co nałożyły się trzęsienia ziemi.

Bardzo zróżnicowane warunki rozwoju siedzib zarządów światowych korporacji przedstawia światowa przestrzeń ekonomiczna, co wpływa na ich różny stopień koncentracji. Najkorzystniejsze warunki w tym zakresie znajdują się na terenie Stanów Zjednoczonych, Japonii i krajów Unii Europejskiej.

Tak duże nakłady finansowe przeznaczone są najczęściej na prowadzenie prac badawczych we własnych ośrodkach naukowo-badawczych, czy innych ośrodkach i uczelniach położonych na terenie krajów, które są także siedzibami zarządów. W wyniku tych prac dochodzi do nowych odkryć i tworzenia nowych konstrukcji, które są opatentowane i w ten sposób chronione przed ich wykorzystaniem przez inne firmy. Najczęściej w bezpośrednim sąsiedztwie zarządów wypracowywane są technologie i dokumentacje techniczne, na podstawie których wykonywane są określone elementy lub prace montażowe. Ich wykonywanie zleca się zwykle oddziałom produkcyjnym znajdującym się na terenie różnych krajów, gdzie występują możliwości obniżenia kosztów produkcji, zwłaszcza dzięki wykwalifikowanej i taniej sile roboczej, tańszej energii, korzystnej infrastrukturze technicznej oraz korzystny klimat dla prowadzenia biznesu. W tej sytuacji na obszarze krajów występowania oddziałów produkcyjnych, czy usługowych nie ma możliwości wdrażania i tworzenia nowych wynalazków nadających się do opatentowania, ponieważ zazwyczaj na ich terenie nie występują segmenty związane z pracami badawczo-rozwojowymi a tylko oddziały wykonujące prace na podstawie przesłanych dokumentacji ${ }^{12}$. Nowe pomysły powstające na ich terenie nie są przydatne dla zarządu korporacji zlokalizowanego za granicą, ponieważ dysponuje on swoimi rozwiązaniami technologicznymi i logistycznymi.

Nakłady finansowe na prace badawczo-rozwojowe mogą pochodzić w zasadzie z dwóch źródeł finansowania, czyli ze środków przedsiębiorstw lub środków publicznych. Regułą jest, że w krajach ekonomicznie rozwiniętych, na terenie których zlokalizowane są

${ }^{12} \mathrm{~W}$ takiej sytuacji trudno o zwiększenie ilości patentów w Polsce, ponieważ fabryki pozostające w strukturach ponadnarodowych korporacji mają zlecane do wykonania prace w oparciu o wypracowane dokumentacje w krajach siedzib zarządów korporacji. Na wzrost liczby patentów mogą wpłynąć krajowe przedsiębiorstwa mające siedziby zarządów na terenie naszego kraju. Jednak bardzo często różny stopień powiązań krajowych przedsiębiorstw wpływa na zakup technologii i urządzeń produkcyjnych za granicą a nie u krajowych producentów. 
zarządy światowych korporacji, przeważająca część nakładów na badania i rozwój pochodzi z przedsiębiorstw, natomiast w pozostałych krajach nakłady finansowe na ten cel pochodzą zazwyczaj ze środków publicznych. Np. w Japonii w strukturze ogólnych nakładów na badania i rozwój przeważający udział, bo $75 \%$, pochodzi z przedsiębiorstw a w Stanach Zjednoczonych - 63\%. Ważnym źródłem finansowania są także środki publiczne, które wynikają z wielkości zamówień, poziomu rozwoju gospodarczego kraju, świadomości działań na polu polityki gospodarczej i naukowej a także zakładanych wizji rozwojowych.

\section{Literatura / References}

Domarecki, K., Petru, R., Czas na nowoczesne uprzemysłowienie. Rzeczpospolita, 30 sierpnia 2012.

Gorzelak, G. (2009). Geografia polskiego kryzysu. Kryzys peryferii, czy peryferia kryzysu. Regional Studies Association - Sekcja Polska. Warszawa.

Kamińska, W., Heffner, K. (red.) (2010). Kapitał ludzki i społeczny w procesie rozwoju obszarów wiejskich. Studia KPZK PAN, t. CXXVI, Warszawa.

Kieżun, W. (2012). Patologia transformacji. Warszawa: Wydawnictwo Poltext.

Kilar, W. (2010). Procesy kształtowania się korporacji Ericsson. Prace Komisji Geografii Przemystu Polskiego Towarzystwa Geograficznego, 16, 153-168.

Kilar, W., Cieluch, M. (2008). Kształtowanie się i organizacja przestrzenna korporacji ponadnarodowej Honda. Prace Komisji Geografii Przemystu Polskiego Towarzystwa Geograficznego, 10, 188-203.

Kudełko, J. (2010). Perspektywy rozwoju regionów Polski Wschodniej w świetle realizowanej polityki rozwoju regionalnego. W: T. Kudłacz (red.), Rozwój regionalny w Polsce w świetle wyzwań XXI w. Studia KPZK PAN, t. CXXXI. Warszawa.

Kudełko, J. (2011). The Meaning of European Cohesion Policy for Regional Development in Poland. Journal on Legal and Economic Issues of Central Europe, vol. 2. STS Science Centre. London.

Kudełko, J. (2013). Determinanty i szanse rozwoju województw Polski Wschodniej. Studia KPZK PAN.

Mikołajewicz, Z. (2003). Uwstecznienie struktury przedmiotowej polskiego przemysłu i jego skutki dla procesów integracji z Unią Europejską. W: J.J. Tomidajewicz (red.), Polityka gospodarcza w procesie akcesji Polski do Unii Europejskiej. Poznań: Wyd. Akademia Ekonomiczna.

Mikołajewicz, Z. (2007). Innowacyjność w przemyśle warunkiem rozwoju gospodarki opartej na wiedzy. W: M. Klamut (red.), Polityka ekonomiczna. Współczesne wyzwania. Warszawa: PWN.

Prusek, A. (2009). Polityka spójności a efektywność społeczno-ekonomiczna. W: Polityka gospodarcza w Polsce i Unii Europejskiejna początku XXI wieku. Katowice: Wyd. Nauk. Akademii Ekonomicznej w Katowicach.

Rachwał, T. (2003). Globalne uwarunkowania restrukturyzacji przedsiębiorstw Polski Południowo-Wschodniej. Prace Komisji Geografii Przemystu Polskiego Towarzystwa Geograficznego, 5, 129138.

Rachwał, T. (2006), Restrukturyzacja technologiczna przedsiębiorstw przemysłowych Polski Południowo-Wschodniej jako czynnik podnoszenia konkurencyjności na rynku międzynarodowym. Prace Komisji Geografii Przemystu Polskiego Towarzystwa Geograficznego, 8, 203-219.

Rachwał, T. (2010). Struktura przestrzenna i działowa przemysłu Polski na tle Unii Europejskich w świetle wybranych mierników. Prace Komisji Geografii Przemysłu Polskiego Towarzystwa Geograficznego, 16, 105-124. 
Sadowski, Z. (2006). Akcesja do Unii Europejskiej a kierunki rozwoju Polski. W: Gospodarcze skutki Akcesji Polski do Unii Europejskiej. Opole: Wyd. Nauk. Uniwersytetu Opolskiego.

Wajda, E. (2003). Proces kształtowania się Motoroli jako firmy ponadnarodowej. Prace Komisji Geografii Przemysłu Polskiego Towarzystwa Geograficznego, 5, 85-114.

Wajda, E. (2006). Rozwój i struktura przestrzenna działalności firmy Nokia w latach 1997-2003. Prace Komisji Geografii Przemystu Polskiego Towarzystwa Geograficznego, 8, 219-240.

Wajda, E., Zalewska, K. (2003). Struktura przestrzenno-organizacyjna korporacji General Motors. Prace Komisji Geografii Przemystu Polskiego Towarzystwa Geograficznego, 6, 119-127.

Zioło, Z., Rachwał, T. (red.) (2006). Międzynarodowe uwarunkowania rozwoju przemysłu. Prace Komisji Geografii Przemystu Polskiego Towarzystwa Geograficznego, 8.

Zioło, Z. (2010). Uwarunkowania kształtowania się procesów transformacji przemysłu i usług. Prace Komisji Geografii Przemystu Polskiego Towarzystwa Geograficznego, 15, 45-60.

Zbigniew Zioło, prof. dr hab., Uniwersytet Pedagogiczny im. Komisji Edukacji Narodowej w Krakowie, Instytut Geografii, Zakład Przedsiębiorczości i Gospodarki Przestrzennej. Doktor nauk przyrodniczych, dr hab. i profesor nauk ekonomicznych. Jego zainteresowania badawcze to: gospodarka przestrzenna, geografia ekonomiczna, polityka społeczno-gospodarcza, ekonomika i polityka rozwoju regionalnego.

Zbigniew Zioło, prof dr hab., Pedagogical University of Cracow, Institute of Geography, Department of Entrepreneurship and Spatial Management.

Sc.D., Ph.D. and Professor of Economics. His research interests are: land management, economic geography, socio-economic policy, economics and policy of regional development.

adres/address: Uniwersytet Pedagogiczny w Krakowie

Instytut Geografii

Zakład Przedsiębiorczości i Gospodarki Przestrzennej

ul. Podchorążych 2, 30-084 Kraków, Polska

e-mail: ziolo@up.krakow.pl 